\title{
A Late Prehistoric Bison Processing Camp in the Central Plains: Montana Creek East (14JW46)
}

\author{
Lauren W. Ritterbush and Brad Logan
}

Bison utilization during the Late Prehistoric period in the central Plains varied from the diffuse pattern that characterizes the Central Plains tradition to the focal pattern of the westernmost Oneota. Both patterns are represented at sites in the Lovewell locality on White Rock Creek, a tributary of the lower Republican River in north-central Kansas. Intensive bison exploitation is also represented at the Montana Creek East (14JW46) site within this locality. Abundant faunal remains indicative of marrow and bone grease processing are associated with the varied, if modest, lithic and ceramic assemblages. These do not suggest use by Oneota or Central Plains tradition peoples although a date fits the Late Prehistoric period. A buried Plains Woodland component, previously undocumented at Lovewell, indicates earlier evidence of bison hunting. Together the remains at this and certain other sites at Lovewell indicate extensive use of bison by different groups.

Keywords: Late Prehistoric, central Plains, marrow extraction, bone grease, Lovewell

Archaeological sites containing bison remains are not unusual on the Great Plains indicating frequent use of this abundant resource over thousands of years. Despite the long-held popular image of Plains Indians as mobile hunters focused on the ever-present bison, much variation exists in the extent to which native peoples utilized this animal. This is especially evident in the central Plains during the Late Prehistoric period (ca. A.D. 1000-1500). During this period, Central Plains tradition $(\mathrm{CPt})$ peoples in Nebraska, northern Kansas, and adjacent areas of Iowa and Missouri harvested a wide variety of plants and animals available to them in their stream valley habitats. Although these often include bison, usually limited quantities and variety of bison elements are present in CPt assemblages. Rather than focusing on bison hunting, many CPt groups pursued a dif- fuse hunter-gatherer-gardener adaptation using a multiplicity of resources. By the middle of the Late Prehistoric period new populations arrived in the region displacing certain $\mathrm{CPt}$ households. These newcomers focused their subsistence activities on bison hunting supplemented with gardening, perhaps in response to climatic change (the Late Medieval Warm period). Archaeological remains tie them to the Oneota tradition, more extensively represented in the Midwest. Oneota sites in the central Plains (White Rock phase) commonly contain numerous bison bones to the near exclusion of those from other animals (Logan 1995, 1998a, 1998b). Canid remains are generally the next most abundant suggesting an important role for dogs. Focal bison hunting allowed Oneota migrants to obtain abundant meat, marrow and fat for food, as well as hides and bones (e.g.,

Lauren W. Ritterbush, Department of Sociology, Anthropology, and Social Work, Kansas State University, 204 Waters Hall, Manhattan, KS 66506

Brad Logan, Department of Sociology, Anthropology, and Social Work, Kansas State University, 204 Waters Hall, Manhattan, KS 66506

Plains Anthropologist, Vol. 54, No. 211, pp. 217-236, 2009 
scapulae) for tools for their direct use and for exchange with others (Ritterbush 2002).

Archaeological investigations of both $\mathrm{CPt}$ and White Rock Oneota sites in the Lovewell locality of north-central Kansas have confirmed these findings. One recently analyzed site, Montana Creek East (14JW46), provides additional evidence of late prehistoric bison hunting. However, questions are raised about the identity of these hunters. The purpose of this article is to describe the assemblage from Montana Creek East and consider its meaning in light of available information for the region.

\section{BACKGROUND}

Much has been learned about Oneota migrants to the central Plains and their indigenous predecessors through investigations of the Lovewell locality. This study area includes present-day Lovewell Reservoir and surrounding lands in Jewell County, north-central Kansas (Figure 1). The archaeological potential of this area was first noted in the 1930s when George Lamb, Paul Cooper, and A. T. Hill of the Nebraska State Historical Society investigated the White Rock site (14JW1) (Rusco 1960). Other sites were recorded nearby when Frank Fenenga (1951) completed a Smithsonian Institution River Basin Survey (SIRBS) project in anticipation of impoundment of White Rock Creek. Lovewell Reservoir was formed through the construction of an earthfill dam across this eastward-flowing tributary of the

Republican River just south of the Kansas-Nebraska border in Jewell County. Excavations at White Rock, Intermill (14JW202), Warne (14JW2), and Russell Mound (14JW207) were conducted by the SIRBS in 1956 under the direction of Robert W. Neuman (1963). Continuing survey and additional investigations of White Rock, Warne, and other sites have been completed over the past 20 years by the authors and others. Much has been learned not only about the archaeology of this relatively small locality in the heart of the central Plains, but about the complex history of human use of the larger region, especially during the Late Prehistoric period.

The most extensive sites at Lovewell are White Rock and Warne, both on low upland ridges on the north side of the reservoir (Figure 1). They were occupied by Oneota migrants approximately A.D. 1300-1450 (Logan 1995, 1998a). The White Rock phase is based on archaeological remains from these sites, which are rich in bison bone, ceramics displaying Oneota forms and decoration, chipped stone tools (e.g., small, triangular unnotched arrowpoints, planoconvex scrapers, and numerous flake tools), ground stone tools (e.g., mauls, shaft abraders), and bone tools (e.g., scapula hoes, awls) (Logan 1995, 1998a; Padilla and Ritterbush 2005; Rusco 1960). Though cache pits abound, the diffuse postmolds uncovered to date are inadequate to delineate shelters or other structures (Logan 1995, 1998a; Rusco 1960). Use of the valley bottoms (now inundated much of the year) is suggested by

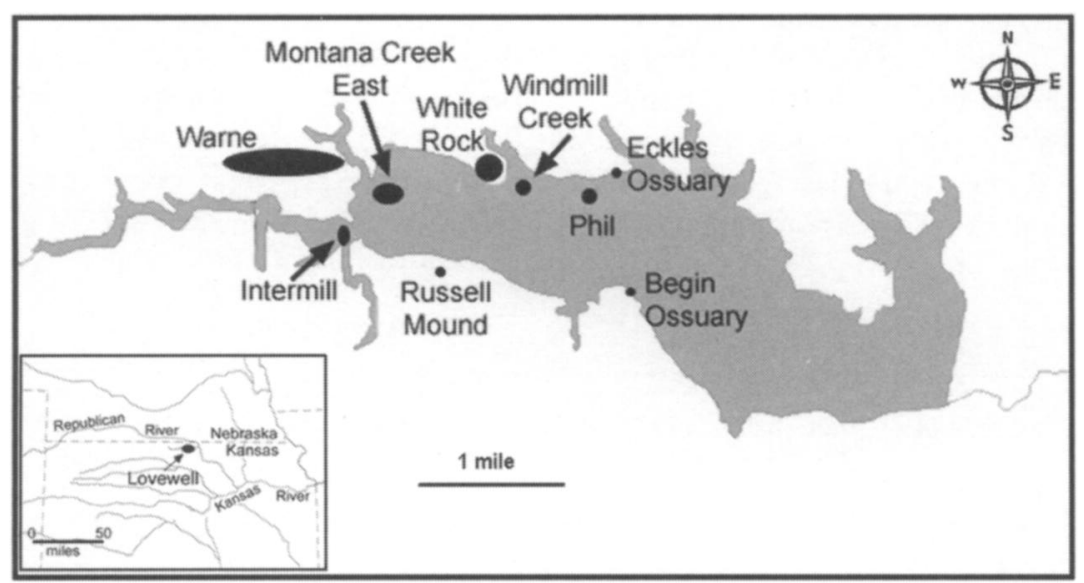

Figure 1. Lovewell Reservoir showing sites discussed in the text. scattered caches of chipped stone and bone hoes. A complete oversized Oneota vessel, along with a grooved axe and possible scapula hoe, were recovered from a pit in a noweroded portion of the valley bottom below the Warne site and west of the Montana Creek East site (Ritterbush and Logan 2006:7-25). These rich site assemblages suggest intensive use of 
the Lovewell locality by Oneota peoples who arrived near the start of the fourteenth century. Although they likely had gardens in the valley, they appear to have focused on bison hunting. A scatter of smaller White Rock sites in surrounding areas of Kansas and Nebraska suggests that Oneota hunters traversed the region in search of bison herds and to exploit lithic source areas in northwestern Kansas (Smoky Hill silicified chalk) and the Flint Hills of eastern Kansas and adjacent Nebraska (where various types of Permian chert outcrop).

In addition to the extensive late prehistoric Oneota sites at Lovewell there are several CPt ossuaries and habitations. The first to be investigated were Russell Mound (14JW207) and Begin ossuary (14JW312) on the south side of the valley (Neuman 1963; Thies 1982) (Figure 1). These burial sites and the more recently discovered Eckles ossuary (14JW4) suggest that CPt habitations existed nearby. This has been confirmed within the last five years through the discovery and investigation of two habitations, both exposed at low flood pool, on the eroded north beach. The Phil (14JW48) and Windmill Creek (14JW49) sites each consist of a single CPt lodge in the bottoms not far from Eckles ossuary (Figure 1). Radiocarbon determinations approximate the time of occupation at about A.D. 1150-1300. Although final results on analyses of recovered remains is pending, the Phil and Windmill Creek assemblages clearly indicate that $\mathrm{CPt}$ adaptation to the Lovewell locality entailed utilization of a diverse array of animal, plant, and stone resources.

\section{MONTANA CREEK EAST} (14JW46)

The Montana Creek East site is inundated much of the year by the flood pool of Lovewell Reservoir. Like Phil and Windmill Creek, it is exposed only in late summer and fall after water has been released for downstream irrigation. Perhaps because of this and its earlier burial below sedi- ments, professional archaeologists were unaware of its existence until 2002. Local artifact collector Mr. Dick Eckles was familiar with finds at this site in the 1960s when he first visited it with his father. At that time bones and artifacts were exposed on a small island formed when reservoir water levels were low. Eckles took the authors here in fall 2002 and has graciously shared his knowledge and artifact collection. The topography of the area has changed dramatically over the past 50 years. At present Montana Creek enters Lovewell Reservoir from the north immediately west of the site (Figure 2). Much of the lower portion of this creek and the channel that once separated the "island" from the north shore in the 1960 s has filled with silt. When the reservoir is low, White Rock Creek flows south of the site meeting Montana Creek by this site. Very little evidence remains of the meandering channel that once separated the "island" from the bottomlands

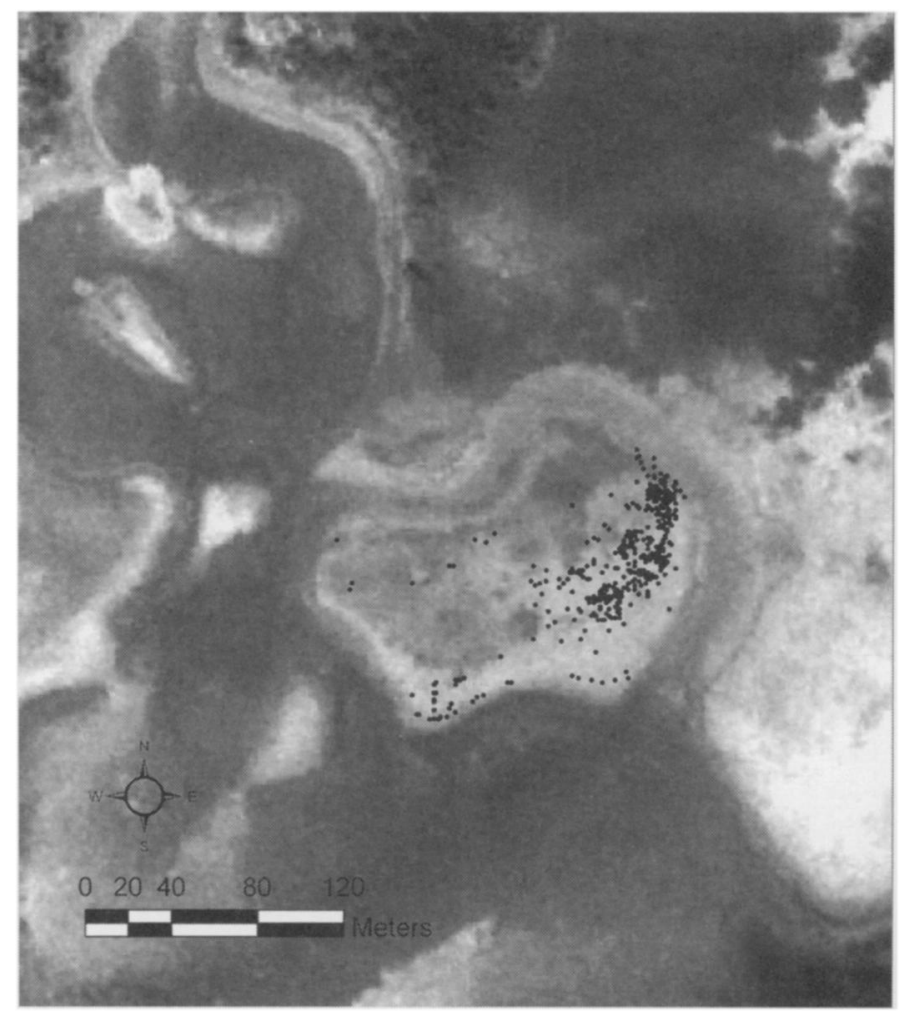

Figure 2. Acrial photograph of Montana Creek at its confluence with White Rock Creek showing piece-plotted bones, artifacts, and bone-artifact clusters at Montana Creek East (Mapping courtesy Christopher Beemer). 
to the north and east where aerial photographs indicate a stream once flowed. Pre-inundation (1941, 1951) and early reservoir (1957) aerial photos show a series of juxtaposed channels or channel scars along the lower reach of Montana Creek and adjacent areas. Given the complex nature of these features along with the dramatic changes associated with modern inundation and siltation, we have been unable to reconstruct the exact setting of the site relative to Montana and White Rock creeks during prehistoric times. It is very possible that this terrace remnant once was situated on the right (or south) bank of and within a tight bend of White Rock Creek. Whether surrounded by the waters of White Rock Creek or Montana Creek during the Woodland and Late Prehistoric periods, this site was adjacent to water and on a discrete landform.

Initial inspection of Montana Creek East revealed a dense scatter of bison bone, some firecracked rock, and very few artifacts. Fortunately Eckles shared with us those artifacts he recalled collecting there. They include triangular unnotched and side-notched arrowpoints, chipped stone knives, drills and gravers, edge-notched bison ribs ("rasps"), bone awls, small shell disk beads, and a cut and perforated piece of thin metal (Ritterbush 2006a). Given the location of the site near the Warne and White Rock sites (approximately 0.32 and $1.1 \mathrm{~km}$ to the west and northeast, respectively), the prevalent form of arrowpoints, and the abundant bison bone, we were inclined to think that the site was Oneota. However, several clues caused us to be cautious about this preliminary interpretation. First, Eckles did not recall seeing any potsherds at this specific site. During our initial visits we found only a couple small sherds near the perimeter of the site that did not match White Rock ceramics. Second, no shell disk beads and edge-notched bison ribs had been reported from White Rock Oneota sites. Third, the form of the gravers also did not match anything from known White Rock assemblages. Finally, the small piece of perforated metal suggested possible protohistoric or historic age. This last find may be a modern artifact, especially since the site is often underwater and fishing is a frequent activity at Lovewell.

National Register of Historic Places investi- gations were conducted by Kansas State University and Burns and McDonnell Engineers in late September 2004 on behalf of the Bureau of Reclamation, Nebraska-Kansas Area Office. These included mapping and collection of all surface artifacts and bones along with excavation of 13 $1 \mathrm{x} 1 \mathrm{~m}$ units to depths of $10-100 \mathrm{~cm}$ below surface. All excavated matrix was dry-screened through 1/4" mesh hardware cloth. Artifacts with at least one dimension $>2.5 \mathrm{~cm}$ were piece plotted and recovered separately from screened materials.

\section{LOWER COMPONENT}

The focus of this article is the upper component at the site. Still, it is important to note that buried deposits were discovered in the southwestern part of the site in two of the deeper excavation units. Cultural materials were associated with the lowest of three buried soil horizons. An Accelerator Mass Spectrometer (AMS) assay of $1860 \pm 40$ B.P. (OS-52831; $\left.\mathrm{d}^{13} \mathrm{C}=23.96\right)$ on a small composite sample of wood charcoal calibrates to a two sigma range of A.D. 67-242 (100 percent probability) (Calib Rev 5.0.2 [Stuiver and Reimer 1993] using the calibration dataset INTCAL04 [Reimer et al. 2004]). This is stratigraphically consistent with a bulk humate date of $1710 \pm 70$ B.P. (ISGS-5714) from the upper part of the $3 \mathrm{Ab}$ horizon of the welded paleosol (William C. Johnson, personal communication 2005). This is the first Woodland component identified at Lovewell Reservoir. Although few test units penetrated this lower cultural zone, it yielded 156 chipped stone artifacts, including five tools, and several bones. The chipped stone tools include a probable drill bit, knife, biface fragment, and two scrapers. Although these are not diagnostic, they compare favorably with artifacts from other Woodland sites in the central Plains. The bone is primarily bison, but includes two possible canid remains and a shed deer antler. Tiny fragments of burned earth and a mud-dauber's nest were also uncovered. Though based on a small window into this earlier occupation, the assemblage suggests a Woodland-age camp or occupation by people who hunted bison. They obtained Smoky Hill silicified chalk from sources to the west and imported them to Montana Creek East where they 
finished and repaired chipped stone tools used for cutting, scraping, and perforating tasks. The burned earth and mud-dauber's nest may indicate structural remains (Ritterbush and Logan 2006:27-37, 74).

\section{UPPER COMPONENT}

Although the Woodland component is significant for its potential information about a poorly known period in this region, the present research focuses on the equally intriguing upper component. Faunal and other remains littered the site surface. These were carefully mapped, and test units dug to determine their vertical extent. These excavations revealed that cultural materials of the upper component were generally confined to the upper $10 \mathrm{~cm}$. Lack of documentation of the site prior to construction of Lovewell Reservoir probably stems from the likelihood that these materials were then buried. Annual fluctuations in flood pool elevation exposed the site to wave action causing erosion of sediments and exposure of subsurface deposits. As a result, much of the upper component is now exposed or very shallowly buried.

\section{Radiocarbon Age}

Our first exposure to the archaeological materials along lower Montana Creek was through preliminary inspection of Dick Eckles' collection. Its inclusion of small unnotched and side-notched arrowpoints, alternatively beveled knives, and other stone artifacts initially led us to interpret late prehistoric or protohistoric age. We sought chronological refinement through radiocarbon assays. Unfortunately the upper component did not yield charcoal useful for radiocarbon dating. Thus, we submitted a sample of bison bone, the most abundant organic material, for AMS dating. The bone selected was a complete second phalange with a mass of $11.3 \mathrm{~g}$ recovered from the $0-10$ $\mathrm{cm}$ level of an excavation unit that also yielded bone-tempered pottery. The resulting assay is $700 \pm 35$ B.P. (OS-55508; $\left.\mathrm{d}^{13} \mathrm{C}-12.37\right)$, which calibrates to a two sigma range of A.D. 1257-1316 and A.D. 1354-1389 (Calib Rev 5.0.2 [Stuiver and Reimer 1993] using the calibration dataset INTCAL04 [Reimer et al. 2004]). The older intercept accounts for 75.8 percent of the probabil- ity distribution. The entire range falls within the Late Prehistoric period. The older range overlaps calibrated dates for Windmill Creek and Phil, CPt lodge sites downstream along White Rock Creek (Logan and Ritterbush 2006). The two sigma range also overlaps the general age of the White Rock phase (A.D. 1300-1450), which appears to immediately post-date CPt occupation of the Lovewell locality. Chronological placement of the White Rock phase is based on six standard radiocarbon assays from the nearby White Rock and Warne sites (Logan 1995, 1998a, 2006). While the AMS date from the upper component at Montana Creek East places it in the Late Prehistoric period, it does not clarify association with either the CPt or the White Rock phase. Descriptive analysis of the Montana Creek East remains was conducted in order to interpret the represented activities and to identify their archaeological affiliation.

\section{Faunal Remains}

The most salient characteristic of the upper component was the large number of bison bones spread widely across the terrace when exposed at low flood pool (Figure 3). Given the frequent association of White Rock phase sites (rather than $\mathrm{CPt}$ ) with abundant bison remains, we felt that these were vital to identifying which and whose activities were represented here. The faunal assemblage exhibits little faunal diversity; very few non-bison remains were recovered. These include one possible turtle bone, two possible bird bones, one deer-sized rib, and the pedicle end of a shed wapiti antler. Of the 440 surface artifacts or artifact clusters that were mapped, 373 were either individual bones, bone clusters, or bone associated with lithics or ceramics. Of the 117 items piece-plotted within the upper levels of the test units, 60 were bison bones. This abundance of bison bone suggested a possible affiliation with White Rock Oneota rather than the CPt.

The rarity of cranial and axial bones in the assemblage reflects the "schlepp effect" (Perkins and Daly 1968). The former are represented by only six pieces (Table 1) and the latter by 79 (Table 2) (Figure 4). The number of identified specimens (NISP) of appendicular pieces (640; discounting unspecified long bone fragments) is significantly 


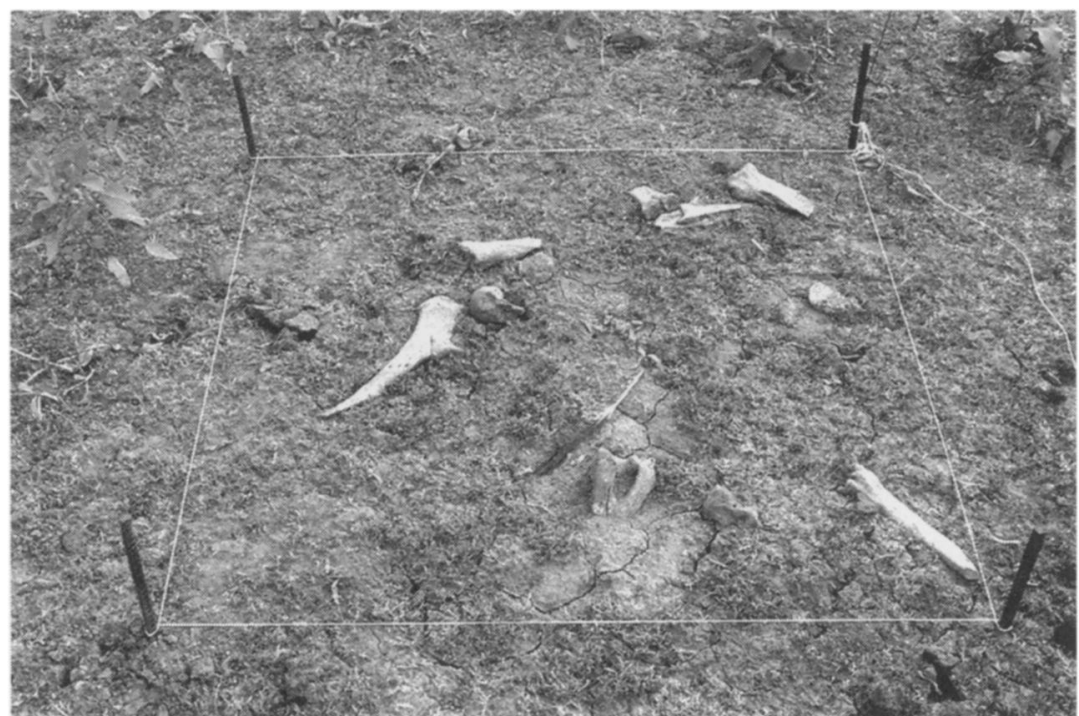

Figure 3. Test Unit 7 showing representative fractured bison bones exposed on the surface.

portion of the tibiae provides the MNI of 42 (while the assemblage includes the same number of left distal humeri, MNI is based on tibiae because 37 of those are complete, three are identical anterior portions, one is juvenile, and the remaining piece is clearly not part of these others). There are distinctly fewer lower appendicular elements (NISP $=60,9.4$ percent). The relative frequency of elements may indicate selection and transport of animal portions based on the caloric

greater (Table 3 ). These are dominated by upper elements (NISP $=580,90.6$ percent) with three elements clearly preferred: humeri, femora, and tibiae (NISP $=459,71.7$ percent). The right distal

Table 1. Bison Cranial Elements from Montana Creek East.

\begin{tabular}{lll}
\hline Element & Portion & Side \\
\hline Petrous & Complete & Left \\
Tooth Enamel & Fragment & \\
Tooth Enamel & Fragment & \\
Upper $1^{\text {st }}$ Molar & Complete & Left \\
Upper ${ }^{\text {th }}$ Premolar & Complete & Left \\
Maxillary Molar & Fragment & \\
\hline Note: NISP $=6$ & &
\end{tabular}

Table 2. Bison Axial Elements from Montana Creek East.

\begin{tabular}{lcccc}
\hline Element & Number & Right & Left & Indeterminate \\
\hline Atlas & - & - & - & - \\
Axis & - & - & - & - \\
Cervical & 2 & - & - & - \\
Thoracic & - & - & - & - \\
Lumbar & 2 & - & - & - \\
Sacral & - & - & - & - \\
Rib & - & 11 & 9 & 55 \\
\hline
\end{tabular}

Note: $\mathrm{NISP}=79$ yield of meat, marrow, or bone grease to Montana Creek East from the kill or butchering site. In this case it is suggested that the elements best reflect marrow processing, a hypothesis tested below.

Prior to testing whether the bones in this component point to selection for marrow, it is necessary to test the hypothesis that their relative frequency is a result of differential preservation due to density-mediated characteristics (Kreutzer 1992). The correlation (Pearson's r) of bison elements (NISP) and their relative volume densities is low and negative $\left(r_{s}=-0.21132\right)$, indicating no significant correlation (even at the 10 percent level of significance) and one inversely related to that characteristic (Table 4). This reflects the low number of bones (e.g., tarsals and vertebrae) with relatively high volume densities. Had volume density accounted for the relative frequency of the elements, we would expect more of those bones, yet the opposite is true.

To test the extent to which the elements reflect various caloric values of bison parts, correlation coefficients were obtained for three different models (Emerson 1990) (Table 4). These are the Total Products model, a measure of combined caloric yield of skeletal fat, muscle protein, and intramuscular and other dissectible fat; Skeletal Fat model, a measure of the caloric yield of 
both marrow and grease (within-bone fat); and Marrow Fat model, a measure of the relative yield of marrow only for each element (Emerson 1990:624, 843, 839). The lowest correlation coefficient of the models is for Total Products and the highest is for Marrow Fat, though the latter only slightly exceeds that for Skeletal Fat (Table 4). The value for the Total Products model is not significant at the 10 percent level, whereas those of the other two models are, even at the 1 percent level of significance. This indicates that bison bones transported to the site were selected primarily for their marrow and grease content, not their flesh. This is not

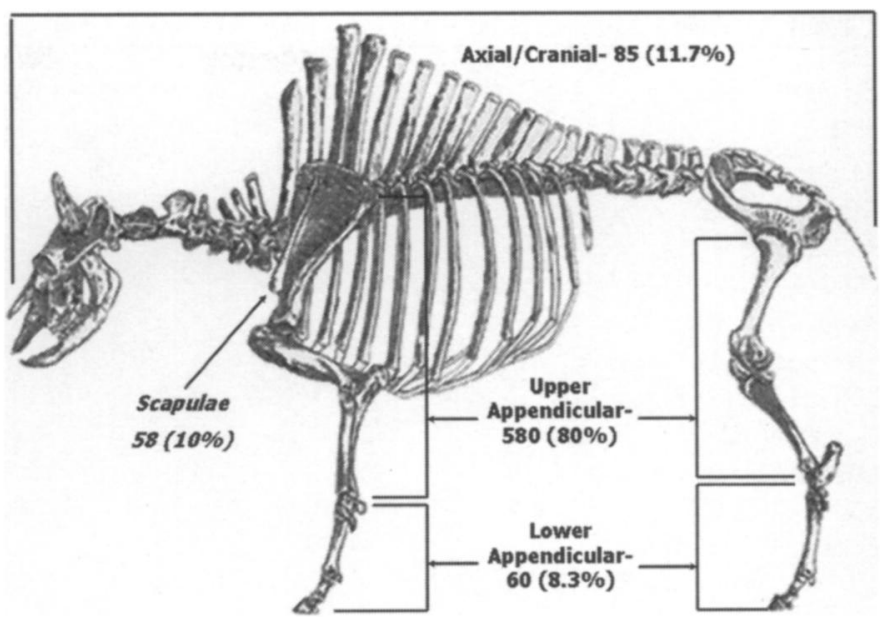

Figure 4. Relative representation of bison elements $(n=725)$ at Montana Creek East. Scapulae are shown as a percentage of upper appendicular elements. to suggest that bison flesh was not used by the site occupants. It is entirely possible that the flesh of some anatomical parts, such as the oft-valued "hump meat" or the haunches, was transported to the site separate from the bones with which they were associated. Inspection of the faunal remains revealed cut marks on only 11 bones, including four rib blades, three tibiae (two diaphysial fragments and one distal piece), a proximal metacarpal, scapula blade, astragalus, and unspecified long bone diaphysis.

It is evident that bison bones chosen for transport to the site were rich in marrow and fat with the former of primary importance. Element breakage also suggests marrow extraction. The vast majority of specimens display spiral fractures that result from cracking elements with a hammer-andanvil technique. As noted below, mauls and a possible anvil were recovered from this component. Similarly, the great majority of identified long bone splinters (and also those unidentified as to element) are not highly comminuted, a pattern typical of bone grease production (Leechman 1951; Vehik 1977; cf. Logan 1998b). The mean length of the 205 tibia fragments is $11.1 \mathrm{~cm}$ (range $=2.1-31.3 \mathrm{~cm}$ ), that for 126 humeri is $10.0 \mathrm{~cm}$ (range $=3.1-21.1 \mathrm{~cm}$ ), and that for 126 femora is $9.0 \mathrm{~cm}$ (range $=2.5-22.8 \mathrm{~cm}$ ). The length of diaphysial fragments is comparable. Thus, the mean length of 66 tibiae shaft pieces is $11.3 \mathrm{~cm}$ (range $=2.9-21.2 \mathrm{~cm})$, that of 33 humeri is $9.95 \mathrm{~cm}$ (range $=4.7-21.2 \mathrm{~cm}$ ), and that of 63 femoral pieces is $10.4 \mathrm{~cm}$ (range $=4.2-22.2 \mathrm{~cm}$ ). Of course, it is possible that the relatively greater length of bone fragments is due to the fact that most of them are surface collected and that more extensive excavations would have yielded a larger sample of smaller pieces that might have been less visible during surface survey. Additional data are needed to verify this interpretation. Nonetheless, the present interpretation is that marrow extraction from bison bones was a significant activity carried out at the site with bone grease production secondary.

\section{Ceramics}

Our initial inspection of the Eckles collection and the artifacts that could be positively attributed to this site revealed a lack of ceramics indicative of archaeological affiliation. One goal of further investigations was to recover diagnostic artifacts. A small sample of 153 sherds was recovered from the surface and upper $10 \mathrm{~cm}$ of the excavation units. Nearly half of these form part of a single reconstructable vessel. The others consist of seven rims, 70 body sherds, and a possible ceramic pipe bowl fragment resulting in a total of 79 analyzable ceramic units. The majority of rim and body sherds are small, and a number are split or eroded. Thus, only limited information about the ceramics could be extracted except in the case 
Table 3. Bison Appendicular Elements from Montana Creek East.

\begin{tabular}{|c|c|c|c|c|c|c|c|c|c|}
\hline \multirow{2}{*}{$\begin{array}{l}\text { Element (NISP) } \\
\text { Side }\end{array}$} & \multicolumn{3}{|c|}{ Proximal $^{\mathrm{a}}$} & \multicolumn{3}{|c|}{ Shaft/Blade } & \multicolumn{3}{|c|}{ Distal } \\
\hline & Right & Left & Ind & Right & Left & Ind & Right & Left & Ind \\
\hline Scapula (58) & - & - & - & 12 & 29 & 5 & 9 & 3 & - \\
\hline Humerus (126) & 9 & 4 & - & 15 & 17 & 2 & 35 & 42 & 2 \\
\hline Radius (25) & 5 & 5 & - & 2 & 4 & - & 3 & 6 & - \\
\hline Ulna (14) & 6 & 6 & - & 1 & - & 1 & - & - & - \\
\hline Radius/Ulna (3) & - & - & - & - & - & - & - & 3 & - \\
\hline Metapodial (1) & - & - & - & - & - & - & - & - & 1 \\
\hline Metacarpal (18) & 4 & 7 & - & - & - & - & 2 & 2 & 3 \\
\hline Ulnar Carpal (2) & - & (2) & - & - & - & - & - & - & - \\
\hline Interm. Carpal (1) & - & (1) & - & - & - & - & - & - & - \\
\hline Radial Carpal & - & - & - & - & - & - & - & - & - \\
\hline Fused $2^{\text {nd }} / 3^{\text {rd }}$ Carpal & - & - & - & - & - & - & - & - & - \\
\hline $4^{\text {th }}$ Carpal (1) & (1) & - & - & - & - & - & - & - & - \\
\hline Accessory Carpal & - & - & - & - & - & - & - & - & - \\
\hline Innominate (4) & $(2)$ & $(2)$ & - & - & - & - & - & - & - \\
\hline Femur (126) & 19 & 22 & 2 & 19 & 32 & 12 & 10 & 10 & - \\
\hline Patella (17) & $(12)$ & $(5)$ & - & - & - & - & - & - & - \\
\hline Tibia (205) & 29 & 31 & - & 22 & 43 & 3 & 42 & 35 & - \\
\hline Lateral Malleolus (2) & - & (2) & - & - & - & - & - & - & - \\
\hline Metatarsal (10) & 2 & 2 & - & - & - & 1 & 1 & 2 & 2 \\
\hline Astragalus (6) & (3) & (3) & - & - & - & - & - & - & - \\
\hline Calcaneus (5) & (2) & (3) & - & - & - & - & - & - & - \\
\hline $1^{\text {st }}$ Tarsal & - & - & - & - & - & - & - & - & - \\
\hline Fused $2^{\text {nd }} / 3^{\text {rd }}$ Tarsal (1) & (1) & - & - & - & - & - & - & - & - \\
\hline Fused Central $/ 4^{\text {th }}$ Tarsal (3) & $(2)$ & (1) & - & - & - & - & - & - & - \\
\hline $1^{\text {st }}$ Phalange (7) & - & - & $(7)$ & - & - & - & - & - & - \\
\hline $2^{\text {nd }}$ Phalange (3) & - & - & (3) & - & - & - & - & - & - \\
\hline $3^{\text {rd }}$ Phalange (2) & - & - & (2) & - & - & - & - & - & - \\
\hline Proximal Sesamoid & - & - & - & - & - & - & - & - & - \\
\hline Distal Sesamoid & - & - & - & - & - & - & - & - & - \\
\hline Long Bone Shaft (49) & - & - & - & - & - & 49 & - & - & - \\
\hline
\end{tabular}

Note: NISP $=689$.

${ }^{\text {a }}$ complete elements are included in this column and are indicated by parentheses.

of the reconstructable vessel.

This well-made vessel has a rounded or globular body with its greatest diameter estimated at $18-22 \mathrm{~cm}$ approximately two-thirds of the height above the base (Figure 5). The shoulders round inward to form a constricted neck above which rises a straight to slightly flaring rim 27.1-29.7 $\mathrm{mm}$ high. The mouth is round with a diameter of $14 \mathrm{~cm}$. There are no handles or other appendages. The pot is relatively small with a vessel height slightly greater than $16 \mathrm{~cm}$ (part of its base is missing). Sherd thickness ranges from 4.6 to $9.3 \mathrm{~mm}$ (thinnest on parts of the upper shoulder). The interior and exterior surfaces are well smoothed with horizontal striations around the rim. The lip is flat to slightly round. The pot is undecorated. Aplastics are not readily visible in the compact paste although small rounded grains of sand are occasionally seen under low-power (10x) magnification. The surface of the vessel is mottled in a variety of colors with the darkest commonly on the upper portion, including on the interior of the rim. Exterior colors range from black and gray to light reddish brown or light red. The core ranges in color from gray to light red. The form and coloring of the pot suggest use as a cooking vessel.

Unfortunately, this set of attributes is culturally non-diagnostic, prohibiting clear identification of affiliation. It does not match ceramics from the nearby White Rock or CPt sites. The paste is 
Table 4. Element Volume Density (Kreutzer 1992), Utility Indices (Emerson 1990), NISP, and Correlation Coefficients for Bison Elements from Montana Creek East.

\begin{tabular}{|c|c|c|c|c|c|}
\hline Element & Vol. Density & [S]MAVGTP & [S]MAVGSKF & [S]MAVGMAR & NISP \\
\hline Cranium & 0.71 & 14.2 & - & - & 6 \\
\hline Mandible & 0.49 & 6.4 & - & - & 0 \\
\hline Atlas & 0.91 & 7.8 & 1.6 & - & 0 \\
\hline Axis & 0.97 & 56.6 & 1.1 & - & 0 \\
\hline Cervical & 0.62 & 84.7 & 3.3 & - & 2 \\
\hline Thoracic & 0.42 & 82.9 & 16.8 & - & 0 \\
\hline Lumbar & 0.39 & 82.9 & 18.3 & - & 2 \\
\hline Rib & 0.57 & 100 & 38.7 & - & 75 \\
\hline Scapula & 0.5 & 31.6 & 53.7 & 36.9 & 58 \\
\hline Humerus (proximal) & 0.25 & 31.6 & 95.6 & 71.5 & 13 \\
\hline Humerus (distal) & 0.48 & 25.1 & 77.2 & 69.2 & $\pi$ \\
\hline Radius (proximal) & 0.48 & 16.5 & 67.4 & 68 & 10 \\
\hline Radius (distal) & 0.35 & 12.1 & 59.1 & 50.3 & 12 \\
\hline Ulna (proximal) & 0.69 & 20.8 & 72.3 & 68.6 & 13 \\
\hline Ulna (distal) & 0.35 & 12.1 & 59.1 & 50.3 & 0 \\
\hline Carpal & 0.43 & 6.6 & 39.2 & 36.2 & 4 \\
\hline Metacarpal (proximal) & 0.59 & 3.9 & 29.2 & 29.2 & 11 \\
\hline Metacarpal (distal) & 0.53 & 2.6 & 24.2 & 18.2 & 8 \\
\hline Innominate & 0.53 & 54.7 & 70.6 & 6.7 & 4 \\
\hline Femur (proximal) & 0.34 & 69.4 & 100 & 97.2 & 43 \\
\hline Femur (distal) & 0.26 & 69.4 & 100 & 98.2 & 20 \\
\hline Tibia (proximal) & 0.41 & 40.8 & 97.1 & 100 & 60 \\
\hline Tibia (distal) & 0.41 & 25.5 & 78 & 84.5 & 77 \\
\hline Astragalus & 0.72 & 13.6 & 51.6 & 55.2 & 6 \\
\hline Calcaneus & 0.8 & 13.6 & 51.6 & 55.2 & 5 \\
\hline Tarsal & 0.65 & 13.6 & 51.6 & 55.2 & 4 \\
\hline Metatarsal (proximal) & 0.52 & 7.5 & 37.5 & 40.6 & 4 \\
\hline Metatarsal (distal) & 0.48 & 4.5 & 30.5 & 25.2 & 5 \\
\hline First Phalanx & 0.48 & 2.4 & 23.5 & 12.85 & 7 \\
\hline Second Phalanx & 0.41 & 2.4 & 23.5 & 12.85 & 3 \\
\hline Third Phalanx & 0.32 & 2.4 & 23.5 & 12.85 & 2 \\
\hline Volume Density & & $r_{s}=-0.21132$ & not significant & $10 \%(0.296)$ & \\
\hline [S]MAVGTP & Total Products Model & $r_{s}=0.284774$ & not significant & $10 \%(0.296)$ & \\
\hline [S]MAVGSKF & Skeletal Fat Model & $r_{s}=0.502691$ & significant & $1 \%(0.463)$ & \\
\hline [S]MAVGMAR & Marrow Fat Model & $r_{s}^{s}=0.557165$ & significant & $1 \%(0.515)$ & \\
\hline
\end{tabular}

hard and compact unlike the relatively soft and often easily eroded White Rock sherds. Likewise, the lack of lip or shoulder decoration differentiates this vessel from most White Rock ceramics. Although $\mathrm{CPt}$ pots also have a globular shape and vertical to slightly flaring rims, their surface treatment is most often

cordmarked, especially in Figure 5. Restored vessel from Montana Creek East.

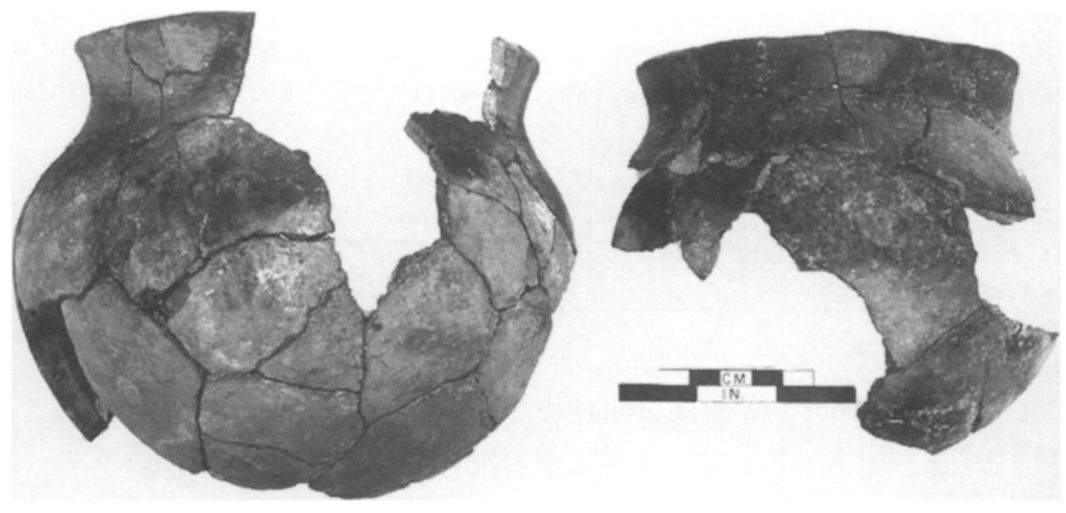


assemblages from north-central Kansas and adjacent portions of Nebraska and specifically from the nearby Windmill Creek and Phil sites (Ritterbush 2006b; Ritterbush and Kobiskie 2007; cf. Blakeslee 1999:172; Kivett 1949; Kivett and Metcalf 1997; Sigstad 1969). Smoothing also is evident in these ceramic assemblages, but generally is not sufficient to completely obliterate all of the original cordmarks. Another possible variation between this and many CPt pots is that sand was used more abundantly as a tempering agent for CPt ceramics.

As in the case of this vessel, 30 percent of the sherds recovered from Montana Creek East lacked discernable temper (Table 5). The remainder exhibits a variety of inclusions, most notably a relatively high percentage (43 percent) of crushed and burned bone. Many of the bone-tempered sherds also include small amounts of fine sand and tiny hematite inclusions and are from and around one excavation unit. They likely derive from a single pot. The few bone-tempered sherds found elsewhere at the site, including a cordmarked and undecorated rim, may be from one or more other bone-tempered vessels. Assuming the first set of sherds is from a single vessel, we can describe that pot as exhibiting both smooth and smoothed-over cordmarking on a mottled light yellowish brown to very dark gray exterior surface. The interior was generally light yellowish brown or pale brown, with a dark gray to very dark gray core. The pot varied in thickness from 6.5$12 \mathrm{~mm}$, with the greatest thickness apparently on part(s) of the body. Although only a small portion of a rim was recovered, it appears to have been straight, forming a mouth about $12 \mathrm{~cm}$ in diameter. The only evident decoration is oblique tool impressions on the relatively flat lip. Another bone-tempered rim from the general site surface varies in that it is vertically cordmarked. The lip is smooth, flat, undecorated, and $4.5-6.2 \mathrm{~mm}$ thick. The rim is vertical, rising approximately 28 $\mathrm{mm}$ above the point of inflection with the upper shoulder, where the pot was about $9.2 \mathrm{~mm}$ thick.

Like the reconstructable vessel, the bonetempered sherds are not diagnostic. The lip decoration is comparable to tool impressions on rims from the nearby Warne and White Rock sites (Neuman 1963; Rusco 1960). In that regard, it resembles Walnut Decorated Lip ceramics. While bone is not a common tempering agent, it may not be completely anomalous for White Rock pottery (the senior author has observed possible bone in a small number of White Rock sherds [Ritterbush 2001]). Still, it was not a preferred temper of Oneota potters. The thickness of the lip $(8.1 \mathrm{~mm})$ falls within the upper range of Walnut Decorated Lip, although other portions of the pot are distinctly thicker than body sherds of that ware, which often range between 4-5 $\mathrm{mm}$ and rarely exceed 8-9 mm (Neuman 1963; Rusco 1960). Although the lip decoration is similar to ceramics from White Rock sites in the vicinity of Montana Creek, this form is also associated with other traditions in the central and southern Plains.

The remaining sherds provide little additional information about the Montana Creek East ceramic assemblage. Many are small, eroded or split and exhibit variability in observable attributes. One especially unusual ceramic object was made with a fine-grained, untempered paste (Ritterbush and Logan 2006:46-47). This almost conical object is roughly $28 \mathrm{~mm}$ high and has a pale brown to light brownish gray exterior and a dark gray inte-

Table 5. Frequencies of Temper Types and Exterior Surface Treatment for Ceramics from Montana Creek East.

\begin{tabular}{lcccccc} 
Surface Treatment & \multicolumn{7}{c}{ Temper Type } \\
\hline & None & Bone & Sand & Shell? & Grit & Totals \\
Smooth & 15 & 21 & 1 & 1 & - & $38(48 \%)$ \\
Cordmarked or Smoothed-over Cordmarks & 4 & 8 & 10 & - & - & $22(28 \%)$ \\
Simple Stamping? & 1 & - & - & - & - & $1(1 \%)$ \\
Brushed & 1 & 2 & - & - & - & $3(4 \%)$ \\
Indeterminate & 3 & 3 & 3 & 5 & 1 & $15(19 \%)$ \\
Totals & $24(30 \%)$ & $34(43 \%)$ & $14(18 \%)$ & $6(8 \%)$ & $1(1 \%)$ & 79 \\
\hline
\end{tabular}


rior. The interior portion of the object is shaped into a bowl of which a goodly portion is missing. A short segment of a rim is present. The lip of this rim tapers to less than $2.5 \mathrm{~mm}$. A broken protrusion with a rounded cross-section and diameter from $11.5-12.3 \mathrm{~mm}$ is on the more complete side of the lower exterior portion. In form, this fragmentary object is suggestive of a pipe, although what might be the stem (broken protrusion) is not perforated. This may be an unfinished or failed attempt at making a ceramic elbow pipe although its final shape and function are uncertain.

\section{Stone Artifacts}

A relatively small sample of stone artifacts was recovered during investigations in 2004. No doubt this is due in part to surface collecting by non-archaeologists since the 1960s. Fortunately, Dick Eckles graciously shared his collection, providing invaluable clues that would not have been available otherwise. In fact, our knowledge of this site and its surface component would be severely limited without this information.

Professional investigation of the site resulted in recovery of 156 pieces of chipped stone debris and 23 chipped stone tools from the upper component. We analyzed an additional 40 chipped stone artifacts in the Eckles collection. Although this sample may not be fully representative, interesting information can be gleaned from it.

The most prevalent lithic material is Smoky Hill silicified chalk (Table 6). Approximately half (50.7 percent) of the chipped stone artifacts were made from this often easily identified material. Although there are no suitable lithic materials available directly within the Lovewell locality, Smoky Hill silicified chalk is considered to be near-local, outcropping in areas west of Jewell
County (Stein 2004, 2006). Permian-age Flint Hills cherts available to the east are represented less frequently (17.4 percent). More "exotic" materials present in small amounts include quartzites (4.6 percent), obsidian (3.2 percent), probable Alibates agatized (or Day Creek) dolomite ( 1.8 percent), and basalt ( 0.5 percent). The materials that we were unable to identify may be variants of silicified chalk and include at least one chalcedony, whitish cherts that range from light gray to pale yellow, and some burned and heated materials. Nearly half of the chipped stone artifacts verified by Eckles to come from the site were made from the colorful Smoky Hill silicified chalk, not too unlike that of the 2004 assemblage. Gray Flint Hills cherts, however, are minimally represented. The frequency of "exotics" is greater in the Eckles collection, though the actual number of artifacts made of these materials remains small. This likely reflects a collection bias focused on tools and artifacts (especially debitage and informal tools) of exotic materials.

Despite limitations of this assemblage it seems clear that a wide variety of lithic materials was selected for chipped stone tools with the heaviest dependence placed on Smoky Hill silicified chalk. Its abundance suggests that the people who utilized this site ranged the High Plains of northwestern Kansas. Their movements or social contacts also extended eastward to the Flint Hills, source of the next most prevalent lithic material. Both materials are well represented at the nearby White Rock, Windmill Creek, and Phil sites, but not with the same frequency. Smoky Hill silicified chalk (and to a lesser extent Flint Hills cherts) is less frequent at Montana Creek East when compared with identified lithic materials in one col-

Table 6. Lithic Raw Materials among Known Chipped Stone Artifacts from Montana Creek East.

\begin{tabular}{|c|c|c|c|c|c|c|c|c|}
\hline & $\begin{array}{l}\text { Smoky Hill } \\
\text { silicified } \\
\text { chalk }\end{array}$ & $\begin{array}{l}\text { Flint Hills } \\
\text { cherts }\end{array}$ & Quartzite & Obsidian & $\begin{array}{l}\text { Alibates } \\
\text { agatized } \\
\text { dolomite }\end{array}$ & Basalt & Unident. & Totals \\
\hline 2004 Collection & $\begin{array}{c}92 \\
(51.4 \%)\end{array}$ & $\begin{array}{c}35 \\
(19.6 \%)\end{array}$ & $\begin{array}{c}4 \\
(2.2 \%)\end{array}$ & $\begin{array}{c}4 \\
(2.2 \%)\end{array}$ & $\begin{array}{l}2 \\
(1.1 \%)\end{array}$ & 0 & $\begin{array}{c}42 \\
(23.5 \%)\end{array}$ & 179 \\
\hline Eckles Collection & $\begin{array}{c}19 \\
(47.5 \%)\end{array}$ & $\begin{array}{c}3 \\
(7.5 \%)\end{array}$ & $\begin{array}{c}6 \\
(15.0 \%)\end{array}$ & $\begin{array}{c}3 \\
(7.5 \%)\end{array}$ & $\begin{array}{c}2 \\
(5.0 \%)\end{array}$ & $\begin{array}{c}1 \\
(2.5 \%)\end{array}$ & $\begin{array}{c}6 \\
(15.0 \%)\end{array}$ & 40 \\
\hline Totals & $\begin{array}{c}111 \\
(50.7 \%)\end{array}$ & $\begin{array}{c}38 \\
(17.4 \%)\end{array}$ & $\begin{array}{c}10 \\
(4.6 \%)\end{array}$ & $\begin{array}{c}7 \\
(3.2 \%)\end{array}$ & $\begin{array}{c}4 \\
(1.8 \%)\end{array}$ & $\begin{array}{c}1 \\
(0.5 \%)\end{array}$ & $\begin{array}{c}48 \\
(21.9 \%)\end{array}$ & 219 \\
\hline
\end{tabular}


lection from White Rock (Ritterbush and Logan 2000). This frequency is offset by greater use of a wide variety of exotic materials.

Although found in small amounts, the presence of varied materials from more distant sources suggests contacts across the Plains, especially to the northwest, west, and south. The distinctive and varied colors of several of the quartzites suggest they may derive from the Hartville Uplift ("Spanish Diggings") of eastern Wyoming. Obsidian from northwestern Wyoming also has been identified. Source analyses of six obsidian flakes from the upper component trace their origins to Obsidian Cliff, Wyoming. Another is most similar to that from Wild Horse Canyon in western Utah (Hughes 2001, 2005, 2006). Neither of these source areas is represented by artifacts from other late prehistoric sites in Kansas. A small sample of CPt obsidian traces to Malad, Idaho, while late prehistoric assemblages from southern Kansas trace to sources in the Jemez Mountains of New Mexico (Robert Hoard, personal communication 2007). Obsidian from the Warne site (White Rock Oneota) has been traced to Malad and Obsidian Ridge (Cerro Toledo), New Mexico (Logan et al. 2001). Four artifacts from Montana Creek East compare macroscopically with Alibates suggesting connections with the Texas panhandle. It should be noted, however, that Day Creek dolomite from southern Kansas and northern Oklahoma is macroscopically similar (Bailey 2000). Whichever material is represented by these artifacts, both derive from sources south of the central Plains. The basalt flake may derive from outwash materials in western Kansas.

Debitage from the upper component of Montana Creek East includes the entire range of raw materials (with exotics such as quartzites, obsidian, and possible Alibates dominant among debitage in the Eckles collection, likely the result of collection bias). The majority of flaking debris is thin, tertiary flakes associated with latestage lithic reduction and maintenance. Many of the complete and broken flakes are very small, indicative of edge retouch and resharpening. Thermal pretreatment was not common as indicated by the relatively low frequency ( 12 percent) of heating and burning. Approximately half of these objects exhibit potlidding or crazing suggesting accidental or uncontrolled heating (Ritterbush and Logan 2006:57).

Chipped stone tools include arrowpoints, knives, scrapers, drills, gravers, a biface fragment, and retouched and utilized flakes. In general, these tools are characteristic of late prehistoric assemblages from the central Plains. This is most evident in the form of the arrowpoints and knives. Six arrowpoints were recovered during visits to the site in 2003 and 2004, while 20 in the Eckles collection were reportedly recovered in recent years. Many more had been collected earlier but could not be accurately sorted out of the larger Eckles collection. Eckles recalled that he and his father found more than 30 complete unnotched and notched points during their first visit to this site in the 1960s (Dick Eckles, personal communication 2006). Two-thirds (66.7 percent) of the points we studied that had intact basal portions are unnotched triangular points. The others have one set of paired side notches (33.3 percent). Complete points range between 15.3 and $35.1 \mathrm{~mm}$ long with a mean of $18.3 \mathrm{~mm}$. All appear to be finished tools rather than preforms (Ritterbush and Logan 2006:58-60). As in the general chipped stone assemblage, the largest number of points (17) is formed from Smoky Hill silicified chalk (65.4 percent). Two each (7.7 percent) are made from Flint Hills cherts and possible Alibates with the remainder (19.2 percent, $\mathrm{n}=5)$ of unidentified materials.

Three complete and one fragment of alternately beveled ('Harahey') knives and two flake knives have also been recovered. The complete beveled knives have been resharpened to varying extents resulting in tools ranging in length from 82.8 to $86.6 \mathrm{~mm}$, in width from 28.0 to $42.5 \mathrm{~mm}$, and in thickness from 6.6 to $8.9 \mathrm{~mm}$. These were made from Smoky Hill silicified chalk (2), Flint Hills chert (1 fragment), and a brown quartzite (1). The flake knives are made from silicified chalk and an unidentified material.

Other chipped stone tools are two drills reworked from side-notched arrowpoints, a T-shaped drill with expanded base, three scrapers, one combined end scraper-graver, three other gravers, a biface fragment, and nine retouched and utilized flakes. Surprisingly, given the frequent occurrence of scrapers at late prehistoric sites and the abun- 
dant bison remains at this particular site, few scrapers were found during the 2004 investigations. Eckles recalls finding scrapers but could not identify those in his collection specifically from Montana Creek East. He observed, however, that this ordinary tool form did not appear to be as abundant there as elsewhere in the Lovewell locality (Dick Eckles, personal communication 2006). Those found during the 2004 investigations consist of a typical plano-convex end scraper, a distal-lateral scraper formed on a small pebble, and a possible bifacial scraper. Steep edge retouch or crushing indicates that several of the retouched and utilized flakes may have served as informal scrapers.

Few ground stone tools have been found at Montana Creek East. One flat stone may have served as a possible anvil or grinding slab. A fragment of a broken cobble exhibits remnants of a shallow groove suggesting use as a maul or hammer. Eckles recalls finding at least one other maul (Dick Eckles, personal communication 2006). Fragments of six quartzite cobbles also may have served grinding or percussion functions. The Eckles collection includes a small piece of faceted ferrous oxide or hematite. Finally, 409 pieces $(4,966.6 \mathrm{~g})$ of heat-fractured limestone (FCR) were recovered from the upper component, especially in one tested area. This material was brought to the site from outcrops in the rugged hills south of the present-day reservoir, possibly for use in bone grease production.

In general, the forms of the above-described lithics compare favorably with chipped and ground stone tools in a variety of late prehistoric assemblages and, thus, are non-diagnostic of any particular archaeological culture. Despite this, there are some qualitative observations that may be significant. First, the greater frequency of unnotched versus side-notched points is generally more similar to Oneota than most CPt assemblages (Owada 1999; Padilla and Ritterbush 2005). Secondly, we are struck by the limited number of scrapers, especially given the large number of bison remains, which suggests hide working was not a significant activity. The large number of arrowpoints and the well-formed alternatively beveled knives, on the other hand, fit well in the tool kits of bison hunt- ers. The specific uses of the drills and gravers are uncertain (although the bits of two of the drills are small enough to be used to drill shell disks for beads, see discussion below). One form of graver found at the Montana Creek East site is distinctive. It is a combination end scraper-graver formed on a flake of Flint Hills chert. The thick end has been unifacially retouched to form a working edge suitable for scraping. The opposite end has been unifacially retouched to a short, thick tapering point useful for engraving.

\section{Bone Tools}

The Eckles collection includes three bone awls, similar to others found throughout the Plains, a perforated piece of bone generally similar to a broad, dull awl, and an antler billet (Ritterbush 2006a:12; Ritterbush and Logan 2006:66). Much more distinctive and numerous are edge-notched bison ribs from the upper component (Figure 6). As noted earlier, many bison bones, including ribs, were scattered over the surface. Most are unmodified. However, Eckles collected 19 that are notched along one or both edges. A comparable rib was recovered in 2004. Many of the modified ribs are incomplete, but have from 4 to 51 notches along one or, in two instances, along opposite edges. The notches are generally ' $V$ '-shaped, although some have a more rectangular cross-section as if made by chopping. Notch widths range from 1.2 to $3.2 \mathrm{~mm}$ and spacing between them varies considerably on individual artifacts and between objects, from 1.2 to $10.5 \mathrm{~mm}$. Smoothing or wear across the modified edge is visible on segments of several of these artifacts suggesting possible use as noise-making rasps.

The large number of notched ribs is unusual. Modified bison ribs occur at archaeological sites in the Plains and adjacent regions, but vary in form and have never been reported in such large number. Two general forms of modified ribs include edge-notched ribs (such as those found at the Montana Creek East site) and ribs with grooves scored across one of the flat (usually lateral) surfaces. The latter form has been found at Plains and Midwestern sites, including one from the White Rock site (Anderson 1994:60, 62-63; Anderson et al. 1995:167; Bray 1991:90-91; Dunlevy and Bell 1936:199; Lintz 1984:332- 


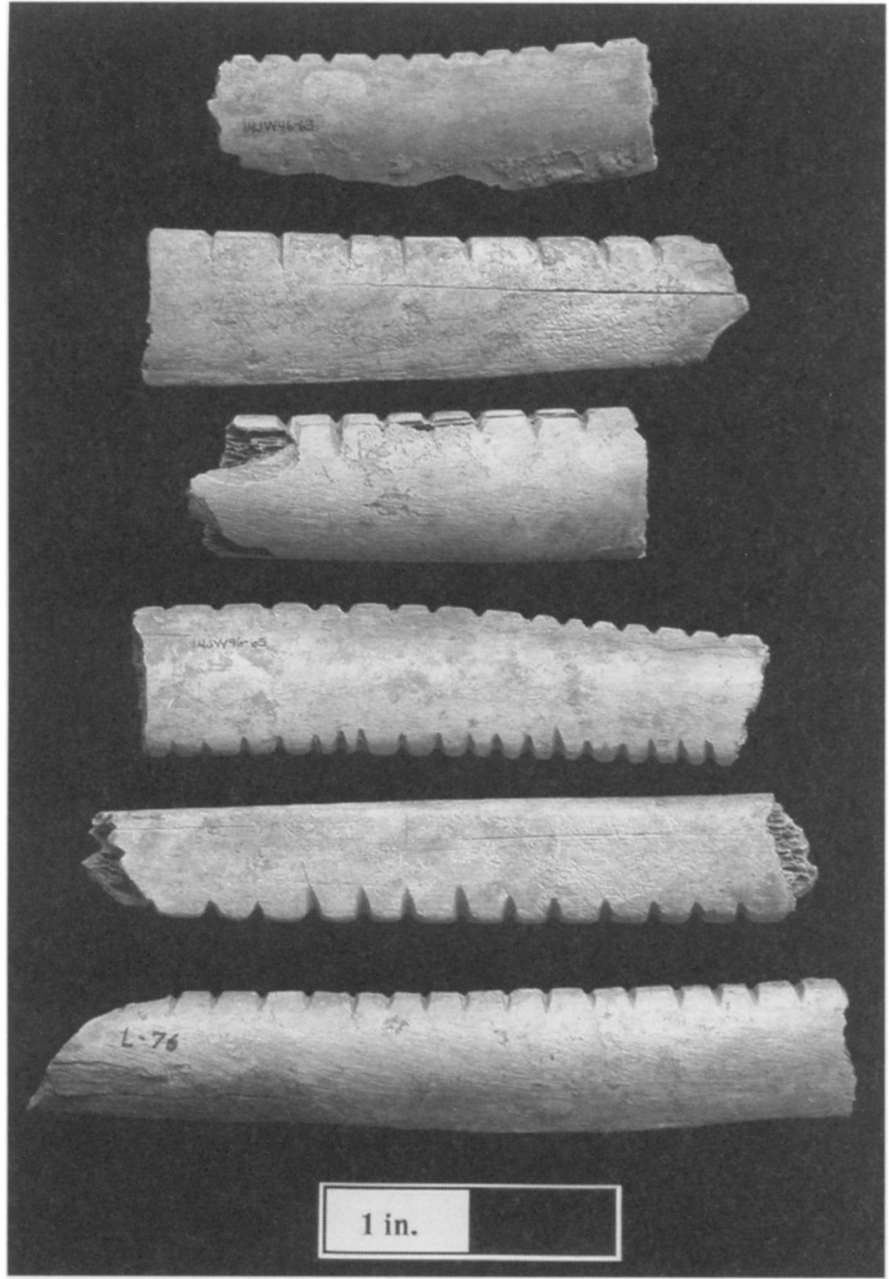

Figure 6. Sample of bison rib rasps in the Eckles collection (Photo courtesy Dick Eckles).

333; Wedel 1959:258, 259, 451-452, 509, 595). Wedel and Hill (1942) suggest that many of these scored ribs and similarly incised vertebral spines (e.g., Neuman 1963:Plate 56) served as pottery paddles, which when pressed against the exterior surface of an unfired pot produced a slightly roughened surface called simple stamping. Simple stamping is associated with certain ceramic styles in the Plains, including some White Rock (Walnut Decorated Lip) ceramics. The edge-notched ribs likely served a different function, perhaps as musical rasps or tally sticks. They have been re- ported in low frequencies at a scattering of sites across the Plains (Beaver 1999:117, 118; Bell 1984:315; Bevitt 1999:90; Garnett et al. 2006; Lawton 1968:67; Pillaert 1963:35; Rohn and Emerson 1984:174, 180; Schneider 1969:159; Wedel and Hill 1942; Alan Potter, personal communication 2006).

\section{Shell Artifacts}

Ten small shell disk beads have been recovered from the surface of the site. They are flat, ranging in thickness from 1.8 to $3.0 \mathrm{~mm}$, and circular with diameters of 4.2-7.2 mm. Each has a perforation $1.8-2.6 \mathrm{~mm}$ in diameter. They have been drilled from one or both sides resulting in uniconical, biconical, and straight perforations (two drills from the site have bits small enough to make perforations this size). Similar beads have been reported from several CPt sites (e.g., Falk 1969:42, 43; Kivett and Metcalf 1997; Wedel 1986:113).

\section{Other Artifacts}

Several metal objects were recovered from Montana Creek East. Given the radiocarbon age, they likely postdate the late prehistoric use of this site. This is most apparent of the impact-deformed bullet from the surface, a small shot ball, part of a large square nail, and another heavily eroded and broken nail from the shallow excavations, all evidence of relatively recent activities (e.g., modern hunting, historic Euroamerican farm activities). Eckles also collected a metal object that is an evenly cut, generally rectangular sheet of thin $(0.3 \mathrm{~mm})$ non-magnetic metal $37.4 \mathrm{~mm}$ long and 16.4-21.8 $\mathrm{mm}$ wide. It has been perforated near one end slightly off-center. The perforation is $1.6 \mathrm{~mm}$ in diameter. Although somewhat bent longitudinally, it is in good condition and is likely part of a recently discarded or lost object (e.g., fishing gear). 


\section{SUMMARY DISCUSSION}

Investigation of the Montana Creek East site (14JW46) in the Lovewell locality of north-central Kansas reveals the unique nature of its archaeological remains within the central Plains. Test excavations uncovered a buried component, the first Woodland-age site to be documented in the archaeologically rich Lovewell locality. Though based on a small window into the past, this assemblage suggests a camp or occupation by Woodland-age bison hunters.

Evidence for bison hunting is also abundant in the upper component. We interpret the surface component as a late prehistoric bison-hunters' camp where marrow, and perhaps bone grease, was processed and other activities (minimally cooking and tool maintenance) were conducted. The age of the site was determined through AMS dating of bison bone associated with cultural materials. The assay of $700 \pm 35$ B.P. (OS-55508), which calibrates to a two sigma range of A.D. 1257-1316 $(p=.758)$, A.D. $1354-1389$ ( $p=.242)$ (Calib 5.0.2 [Stuiver and Reimer 1993] using the calibration dataset INTCAL04 [Reimer et al. 2004]), dates this component to the Late Prehistoric period and most likely to the latter portion of the thirteenth and possibly the fourteenth century. The ceramic and lithic artifacts correlate well with this period. We have struggled, however, to identify a more precise archaeological affiliation.

At least two different late prehistoric archaeological traditions well documented in the central Plains are represented in the Lovewell locality. These include the $\mathrm{CPt}$ representing scattered households of indigenous peoples who subsisted through diffuse hunting, gathering, and gardening. The other, classified as the White Rock phase, reflects the activities of Oneota peoples who migrated from the east into the central Plains. Numerous scattered CPt households are known across much of Nebraska and northern Kansas. Semi-permanent White Rock Oneota settlements are present in the Lovewell locality with camps associated with bison hunting and lithic procurement found elsewhere in the region. In contrast to the indigenous $\mathrm{CPt}$ households, Oneota migrants focused on communal bison hunting and the processing of bison products. The Montana Creek
A Late Prehistoric Bison Processing Camp

East upper component raises the possibility that yet another population hunted bison in or near the Lovewell locality during the Late Prehistoric period.

As yet we have been unable to ascertain the affiliation of the upper component. The abundant bison bones beg comparison to nearby sites of the White Rock phase rather than CPt. Not only are bison well represented at White Rock sites, but the faunal elements recovered from this lowland site are complementary to those in assemblages from the nearby upland Warne and White Rock sites (Logan and Ritterbush 2006). Like the lithics at Montana Creek East, those from the White Rock and Warne sites show preference for Smoky Hill silicified chalk with secondary use of Flint Hills cherts and limited access to more exotic materials (Logan 1995, 1998a; Ritterbush and Logan 2000). Based on these comparisons, it is tempting to interpret the Montana Creek East upper component as a special activity site of Oneota peoples. Several distinctive types of artifacts are present that have not been reported at White Rock Oneota sites. Their presence at Montana Creek East might be explained by the nature of activities carried out at this camp. Edge-notched ribs ("rasps"), for instance, may have been used in a special activity (e.g., dance, celebration, ritual) conducted at this valley bottom location rather than at the nearby upland settlements.

Alternatively, Oneota hunters from the east may have camped here while scouting or exploring the region prior to the movement of larger numbers of migrants and the establishment of the White Rock and Warne settlements. This hypothesis would be supported by the earlier range of the calibrated date associated with the component.

The difficulty with linking the upper component of Montana Creek East with a known archaeological tradition is the lack of clearly diagnostic remains. Ceramics are one of the few distinctive material goods in late prehistoric assemblages that aid in the separation of generally contemporaneous archaeological traditions. Unfortunately, none of the sherds from this site is clearly comparable to either $\mathrm{CPt}$ or Oneota ceramics. Various explanations for the lack of diagnostic pottery might be offered. First, if the site were selected for a 
special activity, unique or atypical pottery may have been used in association with it. If the site was occupied by mobile hunters, they may not have carried many or any breakable pots from their home base. Other containers (e.g., hides, gourds, baskets, wooden bowls) may have been used or atypical vessels made on-site for temporary use. In the first instance, we assume that even special use ceramics would likely display some definitive attributes of the associated pottery-making tradition and, likewise, what little pottery was used by hunters would include them (studies of larger protohistoric and early historic Pawnee hunting camps by Holen [1983] and Roper [1989] show that diagnostic ceramic wares can be identified at some hunting camps). Unfortunately, despite recovery of a small sample of sherds, diagnostic attributes are absent, even from a nearly complete vessel. The latter does not conform to widespread CPt forms or 'typical' White Rock or late prehistoric western Oneota ceramics in terms of paste, form, and decoration. Other potsherds are very small, provide limited information, and do not appear consistent with $\mathrm{CPt}$ or Oneota ceramics.

A distinctive attribute of many of the sherds from the upper component is bone temper. This aplastic does not appear to be diagnostic of any Plains tradition, but it may provide clues to site activities. We wonder whether bone temper reflects expedient production of ceramic vessels for short-term use at special activity sites, such as hunting camps, a suggestion raised by Bozell and Ludwickson (1988) and Toom (1990). These authors report the presence of bone-temper pottery in association with other ceramics at Extended and Post-Contact Coalescent hunting sites in northwestern Nebraska and central South Dakota, respectively. Although a full understanding of the use of crushed bone as a tempering agent is presently lacking, these authors suggest it may have been selected in the absence of other suitable aplastics for on-site manufacture of ceramic vessels. As such, this material may be viewed as an expedient temper, a use consistent with interpretation of Montana Creek East as the camp of bison hunters. The limited quantity of ceramics suggests few pots were used. Perhaps several were made on-site ancillary to the processing of mar- row and bone grease. Obviously, bison bone was readily available for that purpose.

Although bone-tempered pottery is neither common in most of the Plains nor a hallmark of any known late prehistoric culture, its greater frequency in certain regions may suggest connections between the Montana Creek bison hunters and others in the Plains. Beyond the few documented cases in the northern Plains are occurrences of bone temper at sites south of the Lovewell locality. Most geographically proximate are Great Bend sites associated with the Little River focus and the Marion locality. These sites post-date the late prehistoric occupation at Montana Creek (fourteenth through seventeenth centuries A.D.), and bone temper occurs in only a small sample of sherds in certain assemblages (Rohn and Emerson 1984:111-123; Donna Roper, personal communication 2008; Susan Vehik, personal communication 2008; Wedel 1959:500). Farther south, but more comparable in age, are sites in the border region of southern Kansas, western Oklahoma, and the Texas panhandle assigned to the Pratt, Bluff Creek, Odessa, and other archaeological complexes (Berger 2004; Bevitt 1999; Brosowske and Bevitt 2006). General comparison of the Montana Creek East assemblage with a sample of these contemporaneous materials is intriguing. Bison were heavily utilized. Ceramics are regularly globular, tempered with varied materials (e.g., bone, stone, grog, calcium carbonate, or no visible aplastics), smoothed or cordmarked, and include lip and other types of decoration. Forms of chipped stone tools, such as small triangular arrowpoints and beveled knives, are generally similar. Edge-notched ribs have been recovered in small numbers from several sites in south-central Kansas (e.g., Bell and Lundeen [Beaver 1999:117, 118; Bevitt 1999:90] and Pratt [Alan Potter, personal communication 2006]).

Other evidence suggests a relationship between several of these southern Plains groups and Oneota peoples. This is the presence of diagnostic Oneota sherds among indigenous ceramics from at least five sites in southern Kansas (Bevitt 1999; Ritterbush 2006c). Given this evidence of Oneota interaction, along with the noted similarities between some southern Plains and Montana 
Creek East assemblages (minus the Oneota ceramics), we can speculate that a group of Plains hunters with more southerly affiliations visited the Lovewell locality, perhaps during its use by Oneota migrants. Although speculative at this point, we suggest a feast or celebration (dance or ritual possibly using "rasps") may have accompanied marrow and grease extraction activities at Montana Creek East. Such interpretation humanizes the archaeological record while considering the likelihood that multiple activities were pursued. Unfortunately direct support for activities other than marrow and grease processing is weak.

Finally, lithic raw materials raise questions about a proposed link with the southern Plains. Although many southern Kansas late prehistoric assemblages include varied amounts of Smoky Hill silicified chalk, as well as Flint Hills cherts, like Montana Creek East, the former sites commonly include greater amounts of Alibates (or Day Creek dolomite) than has been found in the Lovewell locality. Likewise, materials (e.g., Jemez Mountain obsidian) and artifacts (e.g., Puebloan sherds) suggesting connection between the American Southwest and the southern Plains are familiar in assemblages from the latter region. These are not represented at Montana Creek East. In fact, obsidian and other materials in the assemblage suggest more western and northern rather than southwestern connections.

While thorough understanding of the upper component of the Montana Creek East site evades us, we offer these interpretations. Few ceramic vessels appear to have been used by these mobile hunters. We hypothesize that one or more pots were made on-site using the abundant bone as an expedient tempering material. Other activities also occurred. Ethnographic analogy suggests that rasps were used in a variety of social and ideological contexts associated with music, singing and dance (Garnett et al. 2006). The numerous edge-notched ribs at Montana Creek East may have served as rasps, perhaps as part of communal ritual or ceremonial activities. This may have accompanied feasting on marrow, fat, and possibly flesh imported from the kill site. We cannot identify the cultural affiliation of the site occupants. Given the frequent use of near-local lithic raw materi- als, they must have been from the central Plains or a nearby area. Minor amounts of materials from the northwest, west, and south suggest contact with more distant peoples or locales. We confidently state that bison products, especially marrow and likely bone grease, were processed here during the thirteenth or fourteenth centuries. A hunting party schlepped selected parts of their kill to this stream-side site where the mauls and possible anvils were used to crack bones for marrow extraction. The FCR may represent stone used in preparing bone grease and other food products. Given the minimum number of bison represented $(\mathrm{MNI}=42)$, a sizable volume of meat was available to these hunters and much marrow and grease were produced. Despite the complementary nature of the bison elements from Montana Creek East with regard to their representation at nearby upland White Rock phase sites, we cannot attribute the activities at the former to those of the latter. Thus, it appears that intensive bison hunting and processing characterized the economy of more than one late prehistoric culture in this part of the central Plains. The occupation dates to a time of significant climatic change that may have affected the availability of bison. Perhaps in response to this, migrant groups well organized socially for bison hunting introduced subsistence practices that differed from those of the indigenous Central Plains tradition people. These factors may explain why, by the fourteenth century A.D., the Lovewell locality had become a magnet for bison hunters.

\section{ACKNOWLEDGMENTS}

This research was made possible by the Bureau of Reclamation, especially Bill Chada, Archeologist with the Nebraska-Kansas Arca Office, through funding of continued archaeological investigations at Lovewell Reservoir. Rob Unruh, Rick Cleveland, and other staff of Kansas Wildlife and Parks at Lovewell provided essential logistical support. We extend our thanks to them and to Burns and McDonnell Engineers, Inc., through Dan Shinn for providing qualified personnel for the fieldwork phase of the project. The junior author had the pleasure of working with Mark Latham and his outstanding crew, Tod Bevitt, Mark Darrow, Bob Thompson, and Ransley Welch. Various undergraduate archaeology students at Kansas State University, including Trever Murawski, Tobias Blake, Daniel Keating, and C. Derek Toms, assisted with processing the materials recovered from the site. We are grateful to several individuals for their expertise. Dr. Bill Johnson of the University of Kansas, Department of Geography, recovered and interpreted geomorphologic data relevant to the buried component. Chris 
Beemer, Archeologist and GIS specialist at Ft. Riley, Kansas, helped produce Figure 2. We owe a major debt to Dick Eckles and his wife, Carol. Their generous sharing of knowledge based on many years of association with the Lovewell locality, hospitality, and patience has resulted in an immeasurably better understanding of this and other sites in the area than would be possible through our relatively short-term investigations. Dick is also a skilled photographer and has shared his quality images of artifacts, including Figure 6. We also are grateful to the Plains Anthropologist reviewers, Susan Vehik and one who remains anonymous.

\section{REFERENCES CITED}

Anderson, Adrian, Allan Westover, Terrance J. Martin, Mathew L. Murray, Susan M. T. Myster, Barbara O'Connell, and L. Anthony Zalucha

1995 The State Road Coulee Site: 47Lc176. The Wisconsin Archeologist 76:48-230.

Anderson, Robert P.

1994 Faunal Analysis of Feature 4, 14JW1. In White Rock Revised: Archaeological Investigation of the White Rock and Warne Sites, Lovewell Reservoir, Jewell County, Kansas, edited by Brad Logan, pp. 56-67. Project Report Series No. 85, Museum of Anthropology, University of Kansas, Lawrence.

Bailey, Berkley B.

2000 The Geoarchaeology of Day Creek Chert: Lithostratigraphy, Petrology, and the Indigenous Landscape of Northwest Oklahoma and Southwest Kansas. Unpublished Ph.D. dissertation, Department of Anthropology, University of Oklahoma, Norman.

Beaver, Joseph E.

1999 Faunal Analysis of the Bell Site (14CM407): Implications for Wilmore Complex Subsistence. The Kansas Anthropologist 20:107-122.

Bell, Robert E.

1984 The Plains Villagers: The Washita River. In Prehistory of Oklahoma, edited by Robert E. Bell, pp. 307-324. Academic Press, New York.

Berger, Shelly

2004 Ceramic Artifacts from the Hallman Site (14HP524), A Bluff Creek Complex Site in Harper County, Kansas. The Kansas Anthropologist 25:75-124.

Bevitt, C. Tod

1999 Life on the High Plains Border: Archeological Investigation of Three Late Prehistoric Habitation Sites in Southwest Kansas. The Kansas Anthropologist 20:1-106.

Blakeslee, Donald J.

1999 Waconda Lake: Prehistoric Swidden-Foragers in the Central Plains. Central Plains Archeology 7:1-170.

Bozell, John R., and John Ludwickson

1988 Highway Archeological Investigations at the Slaughterhouse Creek Site and Other Cultural Resources in the Pine Ridge Area. Nebraska State Historical Society report submitted to the Nebraska Department of Roads, Lincoln, Nebraska.

Bray, Robert T.

1991 The Utz Site: An Oneota Village in Central Missouri. The Missouri Archaeologist 52:1-146.
Brosowske, Scott D., and C. Tod Bevitt

2006 Looking South: The Middle Ceramic Period in Southern Kansas and Beyond. In Kansas Archaeology, edited by Robert J. Hoard and William E. Banks, pp. 180-205. University Press of Kansas, Lawrence.

Dunlevy, Marion Lucile, and Earl H. Bell

1936 A Comparison of the Cultural Manifestations of the Burkett (Nance County) and the Gray-Wolfe (Colfax County) Sites. In Chapters in Nebraska Archaeology, edited by Earl H. Bell, pp. 146-247. University of Nebraska, Lincoln.

Emerson, Alice M.

1990 Archaeological Implications of Variability in the Economic Anatomy of Bison bison. Unpublished Ph.D. dissertation, Department of Anthropology, Washington State University, Pullman.

Falk, Carl R.

1969 Bone, Antler, and Shell Artifacts. In Two House Sites in the Central Plains: An Experiment in Archaeology, edited by W. Raymond Wood, pp. 39-44. Memoir 6, Plains Anthropologist 14(44), Pt.2.

Fenenga, Franklin

1951 Appraisal of the Archeological and Paleontological Resources of the Lovewell Reservoir, Jewell County, Kansas. Missouri River Basin Survey, Smithsonian Institution.

Garnett, Rod, Marcel Kornfeld, and Mary Lou Larson

2006 Rasping the Rockies: A Musical Instrument from the Bugas-Holding Site. Paper presented at the $64^{\text {th }}$ Annual Plains Anthropological Conference, Topeka, Kansas.

Holen, Steven R.

1983 Lower Loup Lithic Procurement Strategy at the Gray Site, 25CX1. Unpublished Master's thesis, Department of Anthropology, University of Nebraska, Lincoln

Hughes, Richard E.

2001 Geochemical Research Laboratory Letter Report 200166 from Richard E. Hughes to Lauren W. Ritterbush. Report on file, Kansas State University, Manhattan.

2005 Geochemical Research Laboratory, Letter Report 2005 6. Letter report addressed to Brad Logan. Report on file, Kansas State University, Manhattan.

2006 Geochemical Research Laboratory, Letter Report 2006112. Letter report addressed to Brad Logan. Report on file Kansas State University, Manhattan.

Kivett, Marvin F

1949 Archaeological Investigations in Medicine Creek Reservoir, Nebraska. American Antiquity 14(4, pt. 1):278284.

Kivett, Marvin F., and George S. Metcalf

1997 Prehistoric People of the Medicine Creek Reservoir Frontier County, Nebraska: An Experiment in Mechanized Archaeology (1946-1948). Memoir 30, Plains Anthropologist 42(162).

Kreutzer, Lee Ann

1992 Bison and Deer Bone Mineral Densities: Comparisons and Implications for the Interpretation of Archaeological Faunas. Journal of Archaeological Science 19:271-294.

Lawton, Sherman P.

1968 The Duncan-Wilson Bluff Shelter: A Stratified Site of the Southern Plains. Bulletin of the Oklahoma 
Anthropological Society 16:1-94.

Leechman, Douglas

1951 Bone Grease. American Antiquity 16(4):355-356.

Lintz, Christopher

1984 The Plains Villagers: Antelope Creek. In Prehistory of Oklahoma, edited by Robert E. Bell, pp.325-346. Academic Press, New York.

Logan, Brad

1995 Phasing in White Rock: Archaeological Investigation of the White Rock and Warne Sites, Lovewell Reservoir, Jewell County, Kansas, 1994-1995. Project Report Series No. 90, Muscum of Anthropology, University of Kansas, Lawrence.

1998a Oneota Far West: The White Rock Phase. The Wisconsin Archeologist 79(2):248-267.

1998b The Fat of the Land: White Rock Phase Bison Hunting and Grease Production. Plains Anthropologist 43:349366.

2006 Archaeological Investigations at the Johns Creek and Warne Sites, Lovewell Reservoir, Jewell County, Kansas - 2003. Department of Sociology, Anthropology, and Social Work, Kansas State University, Manhattan report submitted to the Bureau of Reclamation, Nebraska-Kansas Area Office, Grand Island, Nebraska.

Logan, Brad, Richard E. Hughes, and Dale R. Henning

2001 Western Oneota Obsidian: Sources and Implications. Plains Anthropologist 46:55-64.

Logan, Brad, and Lauren W. Ritterbush

2006 Changing Subsistence Patterns in the Late Prehistoric Central Plains: Additional Evidence of Focal Bison Hunting from the Lovewell Locality, North-Central Kansas. Paper presented at the $64^{\text {th }}$ Plains Anthropological Conference, Topeka, Kansas.

Neuman, Robert W.

1963 Archeological Salvage Investigations in the Lovewell Reservoir Area, Kansas. Bureau of American Ethnology Bulletin 185:257-306, Smithsonian Institution, Washington, D.C.

Owada, Isaku

1999 Changes in Late Prehistoric Arrowpoint Technology in North-Central Kansas. Paper presented at the $21^{\text {st }}$ Annual Flint Hills Archacological Conference, Lawrence, Kansas.

Padilla, Matthew J., and Lauren W. Ritterbush

2005 White Rock Chipped Stone Technology. Midcontinental Journal of Archaeology 30(2):259-297.

Perkins, Dexter, Jr., and Patricia Daly

1968 A Hunters' Village in Neolithic Turkey. Scientific American 219(11):97-106.

Pillaert, Elizabeth E.

1963 The McLemore Site of the Washita River Focus. Bulletin of the Oklahoma Anthropological Society 11:1-113.

Reimer, Paula J., Mike G. L. Baillie, Edouard Bard, Alex Bayliss, J. Warren Beck, Chanda J. H. Bertand, Paul G. Blackwell, Caitlin E. Buck, George S. Burr, Kirsten B. Cutler, Paul E. Damon, R. Lawrence Edwards, Richard G. Fairbanks, Michael Friedrich, Thomas P. Guilderson, Alan G. Hogg, Konrad A. Hughen, Bernard Kromer, Gerry McCormac, Stuart Manning, Christopher B. Ramsey, Ron W. Reimer, Sabine Remmel, John R. Southon, Minze Stuiver, Sahra Talamo, F. W. Tayor, Johannes van der Plicht, and
Constanze E. Weyhenmeyer

2004 IntCal04 Terrestrial Radiocarbon Age Calibration, 0-26

Cal Kyr BP. Radiocarbon 46:1029-1058.

Ritterbush, Lauren W.

2001 Temper in White Rock Site Ceramics. Current Archaeology in Kansas 2:7-14.

2002 Drawn by the Bison: Late Prehistoric Native Migration into the Central Plains. Great Plains Quarterly 22(4):259 270.

2006a Eckles Collection from the Montana Creek Sites, Lovewell Locality, Jewell County, Kansas. Current Archaeology in Kansas 6:5-17.

2006b Central Plains Tradition Ceramics from the Lovewell Locality, North-Central Kansas. Paper presented at the $64^{\text {th }}$ Annual Plains Anthropological Conference, Topeka, Kansas.

2006c Late Prehistoric Oneota in the Central Plains. In Kansas Archaeology, edited by Robert J. Hoard and William E. Banks, pp. 151-164. University Press of Kansas, Lawrence. Ritterbush, Lauren W., and Kendra B. Kobiskie

2007 Ceramics. In Windmill Creek: National Register of Historic Places Evaluation of a Central Plains Tradition House Site, Lovewell Reservoir, Jewell County, Kansas 2006 by Brad Logan, pp. 27-34. Department of Sociology, Anthropology, and Social Work, Kansas State University report submitted to the Nebraska-Kansas Area Office, Great Plains Region, Bureau of Reclamation, Grand Island, Nebraska.

Ritterbush, Lauren W., and Brad Logan

2000 Late Prehistoric Oneota Population Movement into the Central Plains. Plains Anthropologist 45:257-272.

2006 The Montana Creek Sites: Archaeological Investigations at Lovewell Reservoir, Jewell County, Kansas, 2004. Department of Sociology, Anthropology and Social Work, Kansas State University report submitted to the Nebraska-Kansas Area Office, Great Plains Region, Bureau of Reclamation, Grand Island, Nebraska.

Rohn, Arthur H., and Alice M. Emerson

1984 Great Bend Sites at Marion, Kansas. Publications in Anthropology 1, Wichita State University, Wichita.

Roper, Donna C. (editor)

1989 Protohistoric Pawnee Hunting in the Nebraska Sand Hills: Archeological Investigations at Two Sites in the Calamus Reservoir. Commonwealth Cultural Resources Group report submitted to the U.S. Department of Interior, Bureau of Reclamation, Great Plains Region, Billings, Montana.

Rusco, Mary Kiehl

1960 The White Rock Aspect. Notebook 4, Laboratory of Anthropology, University of Nebraska, Lincoln.

Schneider, Frederick

1969 The Roy Smith Site, Bv-14, Beaver County, Oklahoma. Bulletin of the Oklahoma Anthropological Society 18:110-179.

Sigstad, John S.

1969 Pottery. In Two House Sites in the Central Plains: An Experiment in Archaeology, edited by W. Raymond Wood, pp. 17-23. Memoir 6, Plains Anthropologist 14(44) Pt.2.

Stcin, C. Martin

2004 Sources of Smoky Hill Silicified Chalk in Northwest 
Kansas. Archeology Office of the Kansas State Historical Society report submitted to the Midwest Archeological Center, National Park Service, Lincoln, Nebraska.

2006 Kansas Lithic Resources. In Kansas Archaeology, edited by Robert J. Hoard and William E. Banks, pp. 264-282. University Press of Kansas, Lawrence.

Stuiver, Minze, and Paula J. Reimer

1993 Extended ${ }^{14} \mathrm{C}$ Data Base and Revised Calib $3.0{ }^{14} \mathrm{C}$ Calibration Program. Radiocarbon 35:215-230.

Thies, Randall M.

1982 The Archeology of the Begin Ossuary, 14JW312, Jewell County, Kansas. Contract Archeology Publication No. 2. Kansas State Historical Society, Topeka.

Toom, Dennis L.

1990 Little Sites, Small Pots, and Plains Village Task Groups. South Dakota Archaeology 14:1-23.
Vehik, Susan C.

1977 Bone Fragments and Bone Grease Manufacturing: A Review of their Archaeological Use and Potential. Plains Anthropologist 22(77):169-182.

Wedel, Waldo R.

1959 An Introduction to Kansas Archeology. Bureau of American Ethnology, Bulletin 174, Smithsonian Institution, Washington, D.C.

1986 Central Plains Prehistory: Holocene Environments and Culture Change in the Republican River Basin. University of Nebraska Press, Lincoln.

Wedel, Waldo R., and A. T. Hill

1942 Scored Bone Artifacts of the Central Great Plains. Proceedings of the United States National Museum 92:91100 , Washington, D.C. 